\title{
Effect of extractant pH on the release of soil phosphorus, aluminium and iron by ammonium fluoride
}

\author{
RAINA NISKANEN \\ University of Helsinki, Department of Agricultural Chemistry, \\ SF-00710 Helsinki, Finland
}

\begin{abstract}
Release of $\mathrm{P}, \mathrm{Al}$ and $\mathrm{Fe}$ of five mineral soils in four-hour extraction by $0.1 \mathrm{M}$ $\mathrm{NH}_{4} \mathrm{~F}, \mathrm{pH} 4.2-8.6$, generally increased with decreasing $\mathrm{pH}$ of the extractant. Fluoride was a rather selective extractant of $\mathrm{Al}$ at $\mathrm{pH}$ 6.1-8.6 where the extractability of iron was low. $\mathrm{NH}_{4} \mathrm{~F}, \mathrm{pH} 4.2$, released a great part of $\mathrm{P}$ solubilized in fractionation of inorganic soil $\mathrm{P}$, and Al was extracted more than by Tamm's acid ammonium oxalate. Acid fluoride solutions released $\mathrm{OH}^{-}$ions from soils. The initial $\mathrm{pH}$ of fluoride was $4.2-5.2$, and it rose in the filtrates of all soils.
\end{abstract}

Index words: amorphous $\mathrm{Al}$ and $\mathrm{Fe}$, fractions of inorganic $\mathrm{P}$, ligand exchange, mineral soils

\section{Introduction}

The use of ammonium fluoride as extractant in the fractionation of inorganic soil phosphorus is based on the assumption that neutral and alkaline fluoride selectively dissolves aluminium-bound phosphate (CHANG and JACKSON 1957, FIFE 1959 a). In the development of the fractionation procedure, natural and synthetic crystalline phosphates were used as model compounds. In fertilized soil, however, phosphate is sooner present as amorphous iron and aluminium phosphates, and it is sorbed on aluminium and iron oxides, these forms of phosphate being more soluble than crystalline phosphates (YUAN et al. 1960, Laverty and McLean 1961).
The efficiency of fluoride as an extractant of phosphate is explained by the stability of the hexafluoroaluminium complex ion in neutral and alkaline solutions (TURNER and RICE 1952). The hexafluoroiron(III) complex, formed in acid solutions, is not stable in neutral and alkaline solutions.

There has been disagreement about the $\mathrm{pH}$ at which ammonium fluoride best distinguishes between aluminium-bound and ironbound phosphate. CHANG and JACKSON (1957) and Chang and Liaw (1962) recommended pH 7.0, while FIFE (1959 a) considered that less hexafluoroiron complex is formed at $\mathrm{pH}$ 8.5 than at $\mathrm{pH}$ 7.0. 


\begin{tabular}{|c|c|c|c|c|c|}
\hline & \multicolumn{5}{|c|}{ Soil sample } \\
\hline & 1 & 2 & 3 & 4 & 5 \\
\hline Sampling depth, cm & $0-20$ & $20-40$ & $20-40$ & $0-20$ & $20-40$ \\
\hline $\mathrm{pH}\left(\mathrm{CaCl}_{2}\right)$ & 5.1 & 4.6 & 4.8 & 5.3 & 5.0 \\
\hline Org. C, \% & 3.6 & 0.8 & 2.6 & 4.4 & 1.0 \\
\hline Clay $(<2 \mu \mathrm{m}), \%$ & 13 & 2 & 47 & 10 & 26 \\
\hline Oxalate-soluble $\mathrm{Al}, \mathrm{mmol} / \mathrm{kg}$ soil & 186 & 104 & 76 & 23 & 11 \\
\hline Oxalate-soluble $\mathrm{Fe}, \mathrm{mmol} / \mathrm{kg}$ soil & 53 & 32 & 224 & 140 & 11 \\
\hline $\mathrm{P}, \mathrm{mmol} / \mathrm{kg}$ soil, extracted by $0.5 \mathrm{M} \mathrm{NH}_{4} \mathrm{~F}(\mathrm{pH} 8.5)$ & 10.4 & 2.3 & 0.8 & 0.7 & 0.2 \\
\hline Fractionated $\mathrm{P}, \mathrm{mmol} / \mathrm{kg}$ soil & 16.4 & 8.0 & 15.7 & 13.3 & 12.5 \\
\hline
\end{tabular}

A previous study showed that the quantities of aluminium and iron released in onehour extraction by alkaline ammonium fluoride in the phosphorus fractionation procedure were small (NISKANEN 1987). The aim of this paper was to study whether the solubility of phosphorus, aluminium and iron is dependent on the $\mathrm{pH}$ of ammonium fluoride in prolonged extraction.

\section{Material and methods}

The material consisted of five mineral soil samples (Table 1) described in a previous paper (NISKANEN 1987). Soil pH was measured in soil-0.01 $\mathrm{M} \mathrm{CaCl}_{2}$ suspension $(1: 2.5$ v/v) (RYTI 1965), the particle-size distribution determined by the pipette method (ELONEN 1971) and organic carbon content by a wet combustion method (Graham 1948). The amorphous aluminium and iron were extracted by acid ammonium oxalate $(0.18 \mathrm{M}$ ammonium oxalate, $0.10 \mathrm{M}$ oxalic acid, $\mathrm{pH}$ $3.3,1: 20 \mathrm{w} / \mathrm{v}, 2 \mathrm{~h})$ (ТАMм 1922) and determined by atomic absorption spectrophotometry.

Quantities of phosphorus, aluminium and iron released in fractionation of inorganic phosphorus (CHANG and JACKSON 1957) of experimental soils are given in a previous paper (NISKANEN 1987). The total values of fractionated phosphorus and values of phosphorus extracted by $0.5 \mathrm{M} \mathrm{NH}_{4} \mathrm{~F}$ (pH 8.5, $1: 50 \mathrm{w} / \mathrm{v}, 1 \mathrm{~h})$ (FIFE $1959 \mathrm{a})$ in connection with fractionation are included in Table 1.
To study the effect of $\mathrm{pH}$ of fluoride solution on the release of phosphorus, aluminium and iron, the soils were extracted in duplicate by $0.1 \mathrm{M} \mathrm{NH}_{4} \mathrm{~F}(1: 200 \mathrm{w} / \mathrm{v}, 4 \mathrm{~h})$, the $\mathrm{pH}$ adjusted to different values with $\mathrm{NaOH}$ and $\mathrm{HCl}$. The extracts were analysed for phosphorus by a molybdenum blue method modified by KAILA (1955) and for aluminium and iron by atomic absorption spectrophotometry.

\section{Results and discussion}

Phosphorus was effectively extracted by 0.1 M NH 4 F, pH 4.2 (Table 2). Four-hour extraction released even more $\mathrm{P}$ than the fractionation procedure (Table 3 ). Acid fluoride did not distinguish between aluminium- and iron-bound phosphate. Obviously, calciumbound $\mathrm{P}$ was also extracted. According to Matzel and Suntheim (1977), apatite phosphorus is solubilized already by neutral fluoride.

The extractability of phosphorus generally tended to decrease with increasing $\mathrm{pH}$ of fluoride (Table 2). Especially in soils Nos 3 and 4 , containing more amorphous iron than aluminium, the extractability of $\mathrm{P}$ decreased efficiently, the $\mathrm{pH}$ of fluoride being 5.2 or higher (Table 2). This was due to diminishing complexation of iron by fluoride.

Basic fluoride, $\mathrm{pH} 8.6$, extracted more $\mathrm{P}$ from soil No. 3 than was released by neutral fluoride ( $\mathrm{pH} 7.1$ ) (Table 2). The same tendency seemed to prevail also in the soils Nos 4 and 5 , although there was no statistically signifi- 
Table 2. Soil $\mathrm{P}, \mathrm{Al}$ and $\mathrm{Fe}\left(\mathrm{mmol} / \mathrm{kg}\right.$ soil) released by $0.1 \mathrm{M} \mathrm{NH}_{4} \mathrm{~F}$ in four-hour extraction*.

\begin{tabular}{|c|c|c|c|c|c|c|}
\hline \multirow{2}{*}{\multicolumn{2}{|c|}{$\begin{array}{l}\text { Soil } \\
\text { No. }\end{array}$}} & \multicolumn{5}{|c|}{$\mathrm{pH}$ of $0.1 \mathrm{M} \mathrm{NH}_{4} \mathrm{~F}$} \\
\hline & & 4.2 & 5.2 & 6.1 & 7.1 & 8.6 \\
\hline \multirow[t]{3}{*}{1} & $\mathrm{P}$ & $20.7^{d}$ & $16.8^{c}$ & $13.3^{\mathrm{b}}$ & $14.3^{\mathrm{b}}$ & $10.3^{\mathrm{a}}$ \\
\hline & $\mathrm{Al}$ & $175^{\mathrm{d}}$ & $135^{\mathrm{c}}$ & $89^{b}$ & $98^{b}$ & $65^{a}$ \\
\hline & $\mathrm{Fe}$ & $10^{c}$ & $4^{b}$ & $2^{a}$ & $3^{\mathrm{ab}}$ & $2^{a}$ \\
\hline \multirow[t]{3}{*}{2} & $\mathrm{P}$ & $7.4^{c}$ & $6.1^{\mathrm{bc}}$ & $4.8^{\mathrm{ab}}$ & $4.8^{\mathrm{ab}}$ & $3.3^{\mathrm{a}}$ \\
\hline & $\mathrm{Al}$ & $130^{\mathrm{d}}$ & $114^{\mathrm{c}}$ & $103^{\mathrm{bc}}$ & $93^{\mathrm{b}}$ & $70^{a}$ \\
\hline & $\mathrm{Fe}$ & $32^{c}$ & $4^{b}$ & $3^{\mathrm{ab}}$ & $3^{\mathrm{ab}}$ & $2^{a}$ \\
\hline \multirow[t]{3}{*}{3} & $\mathrm{P}$ & $5.1^{\mathrm{c}}$ & $1.8^{\mathrm{b}}$ & $1.7^{\mathrm{b}}$ & $1.1^{\mathrm{a}}$ & $1.6^{\mathrm{b}}$ \\
\hline & $\mathrm{Al}$ & $90^{d}$ & $54^{c}$ & $36^{b}$ & $21^{a}$ & $12^{\mathrm{a}}$ \\
\hline & $\mathrm{Fe}$ & $38^{c}$ & $9^{b}$ & $1^{\mathrm{a}}$ & $0^{a}$ & $1^{\text {a }}$ \\
\hline \multirow[t]{3}{*}{4} & $\mathrm{P}$ & $10.0^{\mathrm{s}}$ & $5.4^{b}$ & $2.6^{\mathrm{a}}$ & $2.2^{\mathrm{a}}$ & $2.7^{\mathrm{a}}$ \\
\hline & $\mathrm{Al}$ & $40^{d}$ & $16^{c}$ & $8^{b}$ & $8^{b}$ & $5^{a}$ \\
\hline & $\mathrm{Fe}$ & $76^{e}$ & $26^{d}$ & $2^{a}$ & $3^{b}$ & $4^{c}$ \\
\hline \multirow[t]{3}{*}{5} & $\mathrm{P}$ & $2.9^{\circ}$ & $2.4^{\text {abc }}$ & $2.7^{b c}$ & $1.4^{a}$ & $1.7^{\mathrm{at}}$ \\
\hline & $\mathrm{Al}$ & $38^{\mathrm{c}}$ & $11^{\mathrm{b}}$ & $9^{a b}$ & $5^{\mathrm{ab}}$ & $0^{\mathrm{a}}$ \\
\hline & $\mathrm{Fe}$ & $23^{c}$ & $6^{b}$ & $0^{\mathrm{a}}$ & $0^{\mathrm{a}}$ & $0^{a}$ \\
\hline
\end{tabular}

* Each soil and element tested separately. Values marked with the same letter do not differ at $\mathrm{P}=0.05$.

Table 3. Phosphorus extracted by $0.1 \mathrm{M} \mathrm{NH}_{4} \mathrm{~F}, \%$ of fractionated phosphorus.

\begin{tabular}{lrrrrr}
\hline \multirow{2}{*}{$\begin{array}{l}\text { Soil. } \\
\text { No. }\end{array}$} & \multicolumn{5}{c}{$\mathrm{pH}$ of $0.1 \mathrm{M} \mathrm{NH}_{4} \mathrm{~F}$} \\
\cline { 2 - 6 } & 4.2 & 5.2 & 6.1 & 7.1 & 8.6 \\
\hline 1 & 126 & 102 & 81 & 87 & 63 \\
2 & 93 & 76 & 60 & 60 & 41 \\
3 & 33 & 12 & 11 & 7 & 10 \\
4 & 75 & 41 & 20 & 17 & 20 \\
5 & 23 & 19 & 22 & 11 & 14 \\
\hline
\end{tabular}

cant difference in the means of $\mathrm{P}$ values. The lower extractability by neutral fluoride may be due to phosphate readsorption. Extraction involves the risk of dissolved aluminiumbound phosphate being partially adsorbed on iron oxides (KHIN and LeEPER 1960, FIFE 1962, BRomfield 1967 a, b, RajendRAN and SutTon 1970). Readsorption decreases when the $\mathrm{pH}$ is raised from 7 to 8.5 (KHIN and LEEPER 1960, FIFE 1963). With increasing extractant to soil ratio readsorption decreases (FIFE 1962, 1963). The higher extractability of $\mathrm{P}$ by basic fluoride may also be due to release of iron-bound phosphate (KHIN and LEEPER 1960). Appreciable hydrolysis of iron phosphate occurs at a pH above 7 (CHANG and LiAw 1962), and release of $P$ adsorbed on iron oxide is increased by raising the $\mathrm{pH}$ of fluoride to 8.5 (BROMFIELD $1967 \mathrm{a}$, b).

Apart from soil No. 1, very rich in fluoridesoluble $\mathrm{P}$, basic $0.1 \mathrm{M} \mathrm{NH}_{4} \mathrm{~F}$ extracted more $\mathrm{P}$ during four hours than did $0.5 \mathrm{M} \mathrm{NH}_{4} \mathrm{~F}$ during one hour (Tables 1 and 2). The studies of FIFE $(1962,1963)$ suggest that a one-hour extraction by $\mathrm{NH}_{4} \mathrm{~F}$ does not remove all aluminium-bound phosphate from soils, and that a 24-hour extraction is preferable. The efficiency of $\mathrm{P}$ removal also increases with dilution (FIFE 1962).

Aluminium was poorly extracted within one hour by basic $0.5 \mathrm{M} \mathrm{NH}_{4} \mathrm{~F}$ (NISKANEN 1987), while the four-hour extraction by $0.1 \mathrm{M}$ $\mathrm{NH}_{4} \mathrm{~F}, \mathrm{pH} 8.6$, enhanced the extractability (Table 2). This is in accordance with FIFE (1959 b), who found that increasing amounts of aluminium are dissolved from aluminium oxide by fluoride as the time of extraction is prolonged. The extractability of aluminium tended to increase with decreasing $\mathrm{pH}$ of fluoride (Table 2), at $\mathrm{pH} 4.2$ being even higher than by acid ammonium oxalate (Table 4). In the study of FIFE (1959 b), aluminium was extracted by $0.5 \mathrm{M} \mathrm{NH}_{4} \mathrm{~F}$ from aluminium oxide nearly three times more at $\mathrm{pH} 6.6 \mathrm{com}$ pared with $\mathrm{pH} 9.3$. 
Table 4. Aluminium and iron extracted by $0.1 \mathrm{M} \mathrm{NH}_{4} \mathrm{~F}$, $\%$ of oxalate-extractable.

\begin{tabular}{|c|c|c|c|c|c|c|}
\hline \multirow{2}{*}{\multicolumn{2}{|c|}{$\begin{array}{l}\text { Soil. } \\
\text { No. }\end{array}$}} & \multicolumn{5}{|c|}{$\mathrm{pH}$ of $0.1 \mathrm{M} \mathrm{NH}_{4} \mathrm{~F}$} \\
\hline & & 4.2 & 5.2 & 6.1 & 7.1 & 8.6 \\
\hline \multirow[t]{2}{*}{1} & $\mathrm{Al}$ & 94 & 73 & 48 & 53 & 35 \\
\hline & $\mathrm{Fe}$ & 19 & 8 & 4 & 6 & 4 \\
\hline \multirow[t]{2}{*}{2} & $\mathrm{Al}$ & 125 & 110 & 99 & 89 & 67 \\
\hline & $\mathrm{Fe}$ & 100 & 13 & 9 & 9 & 6 \\
\hline \multirow[t]{2}{*}{3} & $\mathrm{Al}$ & 118 & 71 & 47 & 28 & 16 \\
\hline & $\mathrm{Fe}$ & 17 & 4 & 0 & 0 & 0 \\
\hline \multirow[t]{2}{*}{4} & $\mathrm{Al}$ & 174 & 70 & 35 & 35 & 22 \\
\hline & $\mathrm{Fe}$ & 54 & 19 & 1 & 2 & 3 \\
\hline \multirow[t]{2}{*}{5} & $\mathrm{Al}$ & 345 & 100 & 82 & 45 & 0 \\
\hline & $\mathrm{Fe}$ & 209 & 55 & 0 & 0 & 0 \\
\hline
\end{tabular}

In the fractionation of inorganic soil phosphorus iron was poorly extracted by basic 0.5 $\mathrm{M} \mathrm{NH}_{4} \mathrm{~F}$ (NISKANEN 1987), and four-hour extraction by basic $0.1 \mathrm{M} \mathrm{NH}_{4} \mathrm{~F}$ did not enhance the extractability (Table 2). WiLliams et al. (1971) found that $0.5 \mathrm{M} \mathrm{NH}_{4} \mathrm{~F}$ pH 8.2, extracted less than $2 \%$ of oxalate-extractable iron in non-calcareous lake sediments. The extractability of iron increased only when the $\mathrm{pH}$ of fluoride was 5.2 or lower (Tables 2 and 4).

In the reaction of fluoride solution with soil clays and amorphous oxides, hydroxide ions are released (FIFE 1962, HUANG and JACKSON 1965, Brydon and Day 1970, Perrott et al. 1976). The elevation of $\mathrm{pH}$ in the reaction of fluoride with soil has been used as a test for allophane and aluminium hydroxide in B horizons of podzols (BRYDON and DAY 1970, Perrott et al. 1976). Huang and JackSON (1965) showed that neutral $1 \mathrm{M} \mathrm{NH}_{4} \mathrm{~F}$ reacted primarily with aluminium and thereafter with iron in soil clays and oxides, and the amounts of aluminium and iron solubilized were nearly stoichiometric to the $\mathrm{OH}^{-}$
Table 5. $\mathrm{pH}$ of filtrates.

\begin{tabular}{lccccc}
\hline Soil & \multicolumn{5}{c}{ Initial $\mathrm{pH}$ of $0.1 \mathrm{M} \mathrm{NH}_{4} \mathrm{~F}$} \\
\cline { 2 - 6 } No. & 4.2 & 5.2 & 6.1 & 7.1 & 8.6 \\
\hline 1 & 5.4 & 7.3 & 7.6 & 7.6 & 8.5 \\
2 & 4.7 & 6.6 & 7.6 & 7.6 & 8.5 \\
3 & 5.3 & 6.0 & 6.1 & 6.5 & 8.5 \\
4 & 4.8 & 5.9 & 6.1 & 6.9 & 8.5 \\
5 & 4.7 & 5.5 & 5.9 & 6.8 & 8.5 \\
\hline
\end{tabular}

ions released. In the present study, the $\mathrm{pH}$ values in filtrates (Table 5) showed that hydroxide ions were released in fluoride extraction. At an initial pH 5.2 or lower, $\mathrm{OH}^{-}$ ions were released from all soils. Release of $\mathrm{OH}^{-}$ions, calculated on the basis of a rise in $\mathrm{pH}$, was not stoichiometric to extracted $\mathrm{Al}$ and $\mathrm{Fe}$. This non-equivalence can be ascribed partially to the buffering properties of soil.

The pH-dependence of the extraction pattern coincides with the adsorption theory presented by Hingston et al. (1972). According to this model, adsorption of fluoride on soils and aluminium and iron oxides peaks

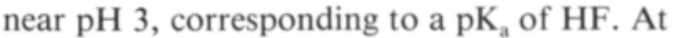
a $\mathrm{pH}$ much below 3 the concentration of $\mathrm{F}^{-}$ is low. With rising $\mathrm{pH}$ the dissociation of $\mathrm{HF}$ and $\mathrm{F}^{-}$concentration increase and fluoride adsorption is enhanced. Any further rise of $\mathrm{pH}$ decreases the sorption of fluoride rather steeply after exceeding the value corresponding to the $\mathrm{pK}_{\mathrm{a}}$ of HF. This is because the concentration of $\mathrm{H}^{+}$ions needed to neutralize $\mathrm{HO}^{-}$ions liberated from oxide surface by ligand exchange with $\mathrm{F}^{-}$decreases.

In a slightly acid $\mathrm{pH}$ region, fluoride seemed to be a selective extractant of aluminium, the extractability of iron being rather low, while acid fluoride extracted both metals. The efficiency of fluoride as extractant is due to the similar size of $\mathrm{F}^{-}$and $\mathrm{OH}^{-}$ions. 


\section{References}

Bromfield, S.M. 1967 a. Phosphate sorbing sites in acid soils. An examination of ammonium fluoride as a selective extractant for aluminum-bound phosphate in phosphated soils. Aust. J. Soil Res. 5: 93-102.

- 1967 b. An examination of the use of ammonium fluoride as a selective extractant for aluminum-bound phosphate in partially phosphated systems. Aust. J. Soil Res. 5: 225-234.

Brydon, J.E. \& DAy, J.H. 1970. Use of the Fieldes and Perrott sodium fluoride test to distinguish the B horizons of podzols in the field. Can. J. Soil Sci. 50: 35-41.

Chang, S.C. \& Jackson, M.L. 1957. Fractionation of soil phosphorus. Soil Sci. 84: 133-144.

- \& Liaw, F.H. 1962. Separation of aluminum phosphate from iron phosphate in soils. Science 136: 386.

Elonen, P. 1971. Particle-size analysis of soil. Acta Agr. Fenn. 122: 1-122.

FIFE, C.V. 1959 a. An evaluation of ammonium fluoride as a selective extractant for aluminum-bound soil phosphate: II Preliminary studies on soils. Soil Sci. 87: $83-88$.

- 1959 b. An evaluation of ammonium fluoride as a selective extractant for aluminum-bound soil phosphate: 1. Preliminary studies on non-soil systems. Soil Sci. 87: 13-21.

- 1962. An evaluation of ammonium fluoride as a selective extractant for aluminum-bound soil phosphate: III. Detailed studies on selected soils (1). Soil Sci. 93: $113-123$.

- 1963. An evaluation of ammonium fluoride as a selective extractant for aluminum-bound soil phosphate: IV. Detailed studies on soils (2). Soil Sci. 96: 112-120.

Graham, E.R. 1948. Determination of soil organic matter by means of a photoelectric colorimeter. Soil Sci. 65: $181-183$.

Hingston, F.J., Posner, A.M. \& Quirk, J.P. 1972. Anion adsorption by goethite and gibbsite. I. The role of the proton in determining adsorption envelopes. J. Soil Sci. 23: 177-192.

Huang, P.M. \& Jackson, M.L. 1965. Mechanism of reaction of neutral fluoride solution with layer sili- cates and oxides of soils. Soil Sci. Soc. Am. Proc. 29: 661-665.

KAILA, A. 1955. Studies on the colorimetric determination of phosphorus in soil extracts. Acta Agr. Fenn. 83: $25-47$.

Khin, A. \& Leeper, G.W. 1960. Modifications in Chang and Jackson's procedure for fractionating soil phosphorus. Agrochimica 4: 246-254.

Laverty, J.C. \& McLean, E.O. 1961. Factors affecting yields and uptake of phosphorus by different crops: 3. Kinds of phosphate - native, applied, and formed. Soil Sci. 91: 166-171.

Matzel, W. \& Suntheim, L. 1977. Eignung der fraktionierten Extraktion als Methode zur Identifizierung definierter Bodenphosphate. Arch. Acker- u. Pflanzenbau u. Bodenk. 21: 879-885.

Niskanen, R. 1987. Release of phosphorus, aluminium and iron in fractionation of inorganic soil phosphorus. J. Agric. Sci. Finl. 59: 141-145.

Perrott, K.W., Smith, B.F.L. \& Inkson, R.H.E. 1976. The reaction of fluoride with soils and soil minerals. J. Soil Sci. 27: 58-67.

Rajendran, N. \& Sutton, C.D. 1970. Re-sorption of soil phosphate during fractionation. J. Soil Sci. 21: 199-202.

RYtı, R. 1965. On the determination of soil pH. J. Scient. Agric. Soc. Finl. 37: 51-60.

Tамм, O. 1922. Eine Methode zur Bestimmung der anorganischen Komponente des Gelkomplexes im Boden. Statens Skogsförsöksanstalt. Medd. 19: 387-404. Stockholm.

Turner, R.C. \& Rice, H.M. 1952. Role of the fluoride ion in release of phosphate adsorbed by aluminum and iron hydroxides. Soil Sci. 74: 141-148.

Williams, J.D.H., Syers, J.K., Armstrong, D.E. \& HARRIS, R.F. 1971. Characterization of inorganic phosphate in noncalcareous lake sediments. Soil Sci. Soc. Am. Proc. 35: 556-561.

Yuan, T.L., Robertson, W.K. \& Neller, J.R. 1960. Forms of newly fixed phosphorus in three acid sandy soils. Soil Sci. Soc. Am. Proc. 24: 447-450.

Ms received December 22, 1987 


\section{SELOSTUS}

\section{Uuttavan ammoniumfluoridiliuoksen pH:n vaikutus maan fosforin, alumiinin ja raudan uuttumiseen}

\section{Raina Niskanen}

Helsingin yliopisto, Maanviljelyskemian laitos, $00710 \mathrm{Helsinki}$

Viidestă kivennāismaasta $0.1 \mathrm{M}$ ammoniumfluoridilla ( $\mathrm{pH} 4.2-8.6$ ) neljässả tunnissa uuttunut fosfori, alumiini ja rauta yleensă lisaaăntyi uuttoliuoksen $\mathrm{pH}: \mathrm{n}$ aletessa. Alumiinin uuttuminen oli melko selektiivistä fluoridiliuoksen $\mathrm{pH}$ :n ollessa $6.1-8.6$, jolloin raudan uuttuminen oli văhäistä. Ammoniumfluoridilla, jonka pH oli 4.2, uuttui suuri osa maan epäorgaanisen fosforin fraktioinnissa vapautuneesta fosforista ja erityisesti alumiinia enemmän kuin Tammin happamella ammoniumoksalaatilla. Happamella fluoridiliuoksella uutettaessa vapautui $\mathrm{OH}^{-}$-ioneja. Kun fluoridiliuoksen alku-pH oli 4.2-5.2, $\mathrm{pH}$ oli kohonnut kaikkien maiden suodoksissa. 